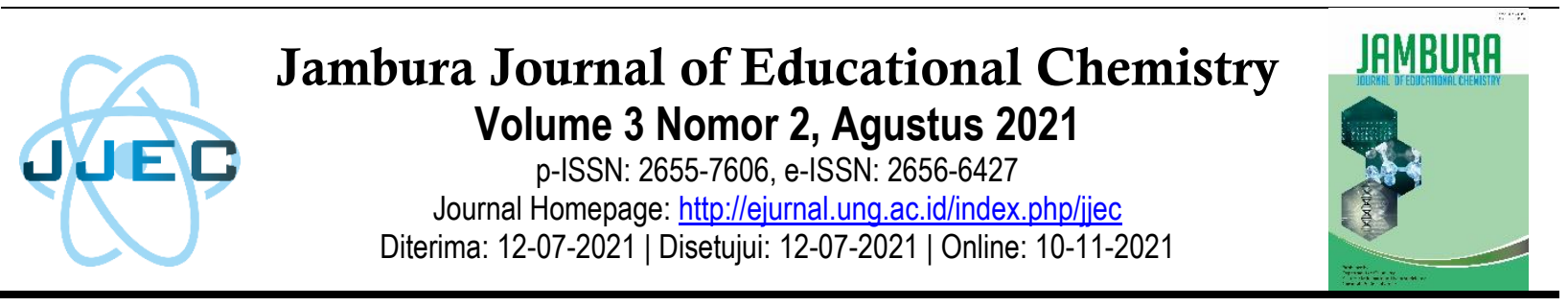

\title{
Peningkatan Hasil Belajar Kimia Dasar Mahasiswa STKIP PI Makassar Melalui Penerapan Model Pembelajaran Kimia Berbasis Concept Mapping Dipadu Teams Games Tournament
}

\author{
Haris Munandar¹, 0pir Rumape ${ }^{2}$ \\ 1,2Jurusan Kimia, Fakultas MIPA, Universitas Negeri Gorontalo \\ e-mail: ${ }^{1}$ harismunandar@ung.ac.id
}

\begin{abstract}
Abstrak
Penelitian ini merupakan Penelitian Tindakan Kelas (Classroom Action Research) yang bertujuan menerapkan model pembelajaran kimia Berbasis Concept Mapping Dipadu Teams Games Tournament untuk meningkatkan hasil belajar kimia dasar mahasiswa STKIP PI Makassar. Adapun subjek penelitian adalah mahasiswa kelas I A, berjumlah 35 mahasiswa. Pelaksanaan ini dilaksanakan dua siklus, dimana setiap siklusnya terdiri dari tiga kali pertemuan dan satu pertemuan evaluasi. Dari hasil kegiatan pembelajaran yang telah dilakukan terjadi peningkatan kategori hasil belajar mahasiswa, pada siklus I berada pada kategori sedang yaitu 10 orang mahasiswa atau 28,58\% dan meningkat di siklus II pada kategori tinggi yaitu 22 orang mahasiswa atau $62,86 \%$, terjadi peningkatan rata-rata hasil belajar mahasiswa yaitu pada siklus I 54,14 dan meningkat pada siklus II menjadi 75,43. Serta peningkatan ketuntasan belajar mahasiswa pada siklus I yaitu 11 orang atau 47.14 dan meningkat pada siklus II menjadi yaitu 31 orang $88,57 \%$. Dengan demikian dapat disimpulkan bahwa model pembelajaran kimia berbasis Concept Mapping dipadu Teams Games Tournament dapat meningkatkan hasil Belajar kimia dasar mahasiswa STKIP PI Makassar.
\end{abstract}

Kata kunci: Hasil Belajar, Concept Mapping, Teams Games Tournament

\section{PENDAHULUAN}

Salah satu upaya yang dapat dilakukan untuk meningkatkan sumber daya manusia yang unggul adalah dengan meningkatkan kualitas pendidikan. Peningkatan kualitas pendidikan dapat dilakukan dengan memperbaiki mutu kegiatan pembelajaran, Hal ini penting karena pendidikan berpengaruh langsung terhadap perkembangan manusia dan segala aspek kehidupannya.

Kimia adalah ilmu pengetahuan yang memegang peranan penting dalam perkembangan IPTEK. Proses globalisasi di era modern seperti saat ini tidak lepas dari peranan ilmu kimia, karenanya perlu mempersiapkan tenaga atau sumber daya manusia yang memiliki pengetahuan kimia yang cukup. Peningkatan kualitas pembelajaran kimia perlu dilaksanakan terus menerus untuk menyesuaikan perkembangan IPTEK.

Pembelajaran kimia yang dilaksanakan hendaknya dilakukan dengan cara yang bervariasi atau dengan menerapkan berbagai model pembelajaran yang bervariasi dan tentunya cocok dengan materi yang diajarkan sehingga peserta didik tidak merasa jenuh dan bosan dengan pelajaran kimia.

Tujuan pembelajaran kimia adalah siswa mampu menguasai konsep-konsep kimia dan menggunakan metode ilmiah yang dilandasi sikap 
ilmiah untuk memecahkan masalah dalam kehidupan sehari-hari. Peningkatan kualitas pembelajaran kimia perlu dilaksanakan terus menerus untuk menyesuaikan perkembangan IPTEK.

Untuk mencapai pembelajaran yang berkualitas, pendidik harus berupaya menciptakan kondisi lingkungan belajar yang dapat membelajarkan peserta didiknya, dapat mendorong peserta didik belajar dan memberi kesempatan peserta didik untuk berperan aktif mengkonstruksi konsep-konsep yang dipelajari. Untuk mencapai tujuan tersebut, pendidik dapat menggunakan pendekatan, strategi, dan model pembelajaran yang inovatif.

Sanjaya (2012) mengungkapkan bahwa pembelajaran didesain untuk membelajarkan siswa, artinya proses pembelajaran itu harus berpusat pada siswa. Maka dari itu, pembelajaran lebih berorientasi pada kegiatan siswa untuk memperoleh hasil belajar berupa perpaduan antara aspek kognitif, afektif, dan psikomotor. Hal ini bisa diartikan bahwa dalam pembelajaran kimia dibutuhkan suatu inovasi model pembelajaran yang bisa membantu peserta didik mencapai tujuan pembelajarannya.

Pembelajaran dikatakan berhasil dan berkualitas apabila setidak-tidaknya sebagian besar peserta didik terlibat secara aktif, baik fisik, mental maupun sosial dalam proses pembelajaran, di samping menunjukan kegairahan belajar tinggi, semangat belajar besar, dan rasa percaya pada diri sendiri. Berdasarkan hal tersebut, upaya guru untuk mengembangkan keaktifan belajar siswa sangat penting, sebab keaktifan siswa menjadi penentu bagi keberhasilan pembelajaran yang dilaksanakan (Mulyasa, 2014)

Berdasarkan observasi awal di STKIP Pembangunan Indonesia (PI) Makassar, mahasiswa cenderung kurang aktif saat dalam pembelajaran kimia dasar. Umumnya hanya sebagian kecil siswa yang berpartisipasi untuk bertanya atau menjawab pertanyaan. Dalam kegiatan diskusi pun, hanya sebagian kecil yang berinisiatif berperan aktif dalam memecahkan masalah.

Menurut (Vitantri, 2017) mahasiswa mengalami kesulitan terkait pemahaman terhadap konsep dikarenakan belum bisa menghubungkan antara konsep satu dengan yang lain dalam suatu materi, sehingga mahasiswa sering lupa konsep lama ketika konsep baru diajarkan.

Salah satu model pembelajaran yang dapat meningkatkan hasil belajar peserta didik yaitu pembelajaran Concept Mapping dipadu dengan Teams Games Tournament. Model pembelajaran ini termasuk dalam pembelajaran kooperatif yang memungkinkan dapat meningkatkan keterlibatan peserta didik dalam pembelajaran sehingga diharapkan bisa meningkatkan hasil belajarnya.

Model kooperatif adalah model pembelajaran yang dilakukan dengan berkelompok yang terdiri dari beberapa peserta yang saling berkerja sama dan membantu untuk mencapai tujuan pembelajaran (Naniastuti et al., 2019). Setiap siswa berkontribusi bagi kelompoknya masingmasing.

Concept Mapping dapat dijadikan sebagai alat untuk mengetahui pemahaman konseptual seseorang. Dengan mengacu pada Concept Mapping maka guru dapat membuat suatu program pengajaran yang lebih terarah dan berjenjang, sehingga dalam pelaksanaan proses belajar mengajar dapat meningkatkan daya serap siswa terhadap materi yang diajarkan. Selain itu, Concept Mapping merupakan suatu gambar dua dimensi dari suatu bidang studi. Ciri inilah yang memperlihatkan hubungan-hubungan proposisional antara konsepkonsep (Williams, 2007).

Novak dan Gowin dalam Hobri (2009) menyatakan bahwa cara meningkatkan hasil belajar pada mata pelajaran sains adalah dengan menggunakan teknik peta konsep (concept mapping). Peta konsep dapat: (1) membuat jelas gagasan pokok bagi guru dan siswa yang sedang memusatkan perhatian pada pokok bahasan; (2) memberikan semacam "peta" jalan yang menunjukkan arah untuk mengaitkan konsep agar menjadi proposisi yang berarti; (3) sebagai ringkasan skematik mengenai apa yang baru saja dipelajari.

Pembelajaran concept mapping adalah salah satu cara yang dapat diterapkan untuk membantu peserta didik mengorganisasi materi pelajaran dengan menyusun ke dalam bentuk 
konsep-konsep yang saling berhubungan. Pembelajaran dengan concept mapping dipandang efektif untuk membantu peserta didik mampu menuangkan pengetahuan apa yang telah mereka ketahui dalam bentuk peta konsep, kemudian mereka dapat mengalami belajar bermakna.

Penelitian (Tarmidzi, 2019) menunjukkan bahwa terdapat peningkatan kemampuan pemahaman konsep mahasiswa yang dibuktikan dengan hasil uji statistika menggunakan Uji $\mathrm{T}$ Sampel Berpasangan. Hal ini menunjukkan efektivitas pembelajaran menggunakan model concept mapping dalam meningkatkan kemampuan pemahaman mahasiswa terutama dalam mata kuliah Konsep Dasar IPA. Betdasarkan hal tersebut kita dapat menyimpulkan bahwa model pembelajaran peta konsep mampu meningkatkan kemampuan pemahaman konsep mahasiswa. Sedangkan penelitian (Darnella et al., 2020) menunjukkan bahwa penerapan pembelajaran concept mapping adanya perbedaan kemampuan berpikir kritis siswa sebelum dan setelah penerapan metode pembelajaran Concept Mapping pada materi Sistem Gerak kelas XI IPA di MAN 1 Palembang.

Adapun model pembelajaran kooperatif tipe TGT adalah suatu model pembelajaran yang mengacu pada belajar klompok siswa untuk menunjukan kemampuan dan keterampilan yang yang dimiliki oleh siswa itu sendiri, kemudian siswa mengikuti turnamen dengan menjawab pertanyaan tentang materi yang dipelajari, (Nurhadi, 2009)

Pembelajaran metode TGT adalah salah satu tipe atau model pembelajaran kooperatif yang mudah diterapkan, melibatkan aktivitas seluruh siswa tanpa harus ada perbedaan status, melibatkan peran siswa sebagai tutor sebaya, dan mengandung unsur permainan serta reinforcement (Hamdayama, 2016).

Model pembelajaran kooperatif tipe TGT bisa membuat siswa belajar dengan santai, disamping itu juga ikut menimbulkan persaingan sehat, kerja team dan bertanggung jawab serta berpartisipasi aktif dalam belajar. Dengan demikian dapat menumbuhkan motivasi siswa untuk belajar. Hal ini terlihat dari antusias semua siswa dalam kelas untuk menjadi "Super Team" dalam turnamen, sehingga memberi pengaruh yang sangat baik terhadap hasil belajarnya. Motivasi belajar yang tinggi dapat meningkatkan hasil belajar siswa (Pongkendek et al., 2019)

Model Pembelajaran kooperatif tipe TGT sangat memungkinkan memberikan kesempatan pada peserta didik untuk berfikir, menjawab, dan saling membantu satu sama lain dan akan menambah variasi model pembelajaran yang menarik, menyenangkan, meningkatkan aktivitas dan kerjasama siswa. Salah satu keunggulan dari model pembelajaran TGT menurut Taniredja (2011) yaitu interaksi belajar siswa dalam kelas menjadi aktif dan tidak membosankan.

Berdasarkan penelitian yang dilakukan (Ratieh \& Fachrurrozie, 2014) terlihat bahwa adalah: (1) penerapan strategi pembelajaran Teams Games Tournament (TGT) pada mata kuliah Akuntansi Keuangan Menengah (AKM) 2 terbukti efektif dalam meningkatkan keaktifan belajar mahasiswa; (2) Penerapan strategi pembelajaran Teams Games Tournament (TGT) pada mata kuliah AKM 2 terbukti efektif dalam meningkatkan hasil belajar mahasiswa.

Tujuan dari concept mapping ialah menyelidiki apa yang telah diketahui siswa, belajar bermakna, mengungkapkan konsepsi yang salah pada siswa, dan sebagai alat evaluasi. Concept mapping dapat diterapkan secara berkelompok maupun individu. Sedangkan model pembelajaran TGT adalah salah satu model pembelajaran kooperatif yang mudah diterapkan, melibatkan aktivitas seluruh siswa tanpa harus ada perbedaan status. Aktivitas belajar dengan permainan yang dirancang dalam pembelajaran kooperatif tipe TGT memungkinkan siswa dapat belajar lebih rileks disamping menumbuhkan tanggung jawab, kejujuran, kerja sama, persaingan sehat dan keterlibatan belajar. Kedua model pembelajaran ini dianggap bisa menjadi inovasi dalam pembelajaran untuk membantu peserta didik mencapai tujuan pembelajarannya.

Melalui uraian latar belakang diatas, maka penulis bermaksud untuk meneliti Peningkatan Hasil Belajar Kimia Dasar Mahasiswa STKIP PI Makassar Melalui Penerapan Model Pembelajaran Kimia Berbasis Concept Mapping Dipadu Teams Games Tournament. 


\section{METODE PENELITIAN}

\section{Jenis Penelitian}

Penelitian ini merupakan penelitian tindakan kelas (PTK) yang difokuskan memberi informasi sebagai upaya peningkatan hasil belajar kimia dasar mahasiswa.

\section{Waktu dan Tempat Penelitian}

Penelitian ini dilaksanakan selama tiga bulan dari bulan Juli-Agustus 2019. Lokasi penelitian ini dilaksanakan di STKIP PI Makassar semester ganjil Tahun Akaademik 2019/2020.

\section{Subjek Penelitian}

Penelitian ini dilaksanakan di kelas I A Program Studi pendidikan biologi STKIP PI Makassar semester ganjil tahun ajaran 2018/2019 dengan jumlah siswa 35 orang mahasiswa terdiri dari 15 laki-laki 20 siswa perempuan.

\section{Prosedur Penelitian}

Prosedur kerja dalam penelitian ini terdiri dari beberapa tahapan, yakni : Perencanaan (planning); Tindakan (acting); Observasi (observing); Refleksi (reflecting). Selanjutnya siklus tersebut akan berulang terus sehingga membentuk spiral. Banyaknya siklus yang dilakukan tergantung pada peningkatan hasil belajar.

\section{Teknik Pengumpulan Data}

Teknik pengumpulan data dalam penelitian terdiri dari tes hasil belajar dan lembar obesrvasi aktivitas mahasiswa. Tes hasil belajar terbagi atas dua yaitu pre-tes dan dan post-tes. Sebelum melaksanakan proses pembelajaran, diberikan tes awal untuk mengidentifikasi tingkat kesulitan materi dan menyamakan persepsi awal terkait rencana pembelajaran. Setelah pembelajaran selesai, guru memberikan lagi tes akhir, untuk mengetahui daya serap siswa terhadap materi yang telah diajarkan.

Teknik ini digunakan untuk memperoleh data mengenai peningkatan hasil belajar mahasiswa dalam proses pembelajaran dengan menggunakan model pembelajaran concept mapping dipadu teams games tournament dengan menggunakan lembar observasi aktivitas mahasiswa.

\section{Teknik Analisis Data}

Data hasil belajar mahasiswa dianalisis kemudian nilai yang diperoleh dikategorikan menjadi beberapa kategori yakni: sangat tinggi, tinggi, sedang, rendah, dan sangat rendah. Data prestasi yang diperoleh dikategorikan berdasarkan tehnik kategori standar yang ditetapkan.

Teknik analisis data yang digunakan dalam penelitian ini terdiri dari dua bagian yaitu analisis data deskriptif dan analisis data inferensi. Menurut Sugiyono (2011) analisis data deskriptif ini digunakan untuk mendeskripsikan atau menggambarkan data yang telah didapatkan, sedangkan analisis data inferensial digunakan untuk menguji hipotesis penelitian.

Tabel 1. Kategori Hasil Belajar Siswa

\begin{tabular}{cc}
\hline Nilai & Skor \\
\hline $0-34$ & Sangat Rendah \\
$35-54$ & Rendah \\
$55-69$ & Sedang \\
$70-84$ & Tinggi \\
$85-100$ & Sangat Tinggi \\
\hline
\end{tabular}

Untuk memperoleh presentase skor hasil belajar siswa, digunakan teknik analisis data yaitu dengan rumus sebagai berikut:

$\mathrm{P}=\frac{\mathrm{F}}{\mathrm{N}} \times 100 \%$

Keterangan:

$\mathrm{P}=$ Persentase

$\mathrm{F}=$ Frekuensi aktifitas siswa

$\mathrm{N}=$ Banyaknya individu

\section{HASIL DAN PEMBAHASAN}

Siklus I

Aktivitas belajar hasil observasi

Tabel 2. Aktivitas Mahasiswa Dalam Pembelajaran Siklus I

\begin{tabular}{|c|c|c|c|c|c|c|c|}
\hline \multirow[b]{2}{*}{ NO } & \multirow{2}{*}{$\begin{array}{c}\text { AKTIFITAS } \\
\text { SISWA }\end{array}$} & \multicolumn{3}{|c|}{ PERTEMUAN } & & \multirow{2}{*}{$\begin{array}{l}\text { RATA } \\
\text { RATA }\end{array}$} & \multirow[b]{2}{*}{$(\%)$} \\
\hline & & I & II & $\begin{array}{c}\text { II } \\
\text { I }\end{array}$ & & & \\
\hline 1 & $\begin{array}{l}\text { Mendengarkan } \\
\text { penjelasan guru }\end{array}$ & 26 & 29 & $\begin{array}{l}3 \\
1\end{array}$ & $\begin{array}{l}\mathbf{T} \\
\mathbf{E}\end{array}$ & 28.67 & 81.91 \\
\hline 2 & $\begin{array}{l}\text { Menyusun } \\
\text { pertanyaan dan } \\
\text { mencari } \\
\text { jawaban }\end{array}$ & 10 & 14 & $\begin{array}{l}1 \\
5\end{array}$ & $\mathbf{S}$ & 13 & 37.47 \\
\hline
\end{tabular}




\begin{tabular}{|c|c|c|c|c|c|c|c|c|c|c|c|c|c|c|}
\hline 3 & $\begin{array}{l}\text { Aktif dalam } \\
\text { diskusi } \\
\text { kelompok }\end{array}$ & 19 & 22 & 23 & $\begin{array}{l}\mathbf{S} \\
\mathbf{I}\end{array}$ & 21.33 & 60.94 & 4 & $\begin{array}{l}\text { Menyampaikan } \\
\text { ide } \\
\text { Mengajukan }\end{array}$ & 16 & 17 & $17 \quad$ II & 16.67 & 47.67 \\
\hline 4 & $\begin{array}{l}\text { Menyampaikan } \\
\text { ide }\end{array}$ & 12 & 13 & 15 & $\begin{array}{l}\mathbf{K} \\
\mathbf{L} \\
\mathbf{U}\end{array}$ & 13.33 & 38.08 & 5 & $\begin{array}{l}\text { pertanyaan pada } \\
\text { saat pembelajaran }\end{array}$ & 9 & 19 & 12 & 10.33 & 29.51 \\
\hline 5 & $\begin{array}{l}\text { Mengajukan } \\
\text { pertanyaan pada } \\
\text { saat pembelajaran }\end{array}$ & 7 & 8 & 9 & S & 8 & 22.85 & 6 & $\begin{array}{l}\text { Menjawab } \\
\text { pertanyaan dari } \\
\text { siswa lain }\end{array}$ & 10 & 11 & 12 & 11 & 31.43 \\
\hline
\end{tabular}

$$
\begin{array}{llllll}
\begin{array}{l}
\text { pertanyaan dari } \\
\text { siswa lain }
\end{array} & 7 & 8 & 10 & 7,3 & 20.85 \\
\hline
\end{array}
$$

Tabel 5. Distribusi Frekuensi dan Persentase Hasil

\section{Hasil Belajar}

Tabel 3. Distribusi Frekuensi dan Persentase Hasil

\begin{tabular}{|c|c|c|c|c|}
\hline No & Interval & Kategori & Frekuensi & $\begin{array}{c}\text { Persentase } \\
(\%)\end{array}$ \\
\hline 1 & $0-34$ & $\begin{array}{l}\text { Sangat } \\
\text { Rendah }\end{array}$ & 2 & 5.71 \\
\hline 2 & $35-54$ & Rendah & 15 & 42.86 \\
\hline 3 & $55-69$ & Sedang & 10 & 28.58 \\
\hline 4 & $70-84$ & Tinggi & 6 & 17.14 \\
\hline 5 & $85-100$ & $\begin{array}{l}\text { Sangat } \\
\text { Tinggi }\end{array}$ & 2 & 5.71 \\
\hline \multicolumn{3}{|c|}{ Jumlah } & 35 & 100 \\
\hline
\end{tabular}
Belajar Kimia Siklus I

Dari hasil refleksi siklus I dapat dilihat beberapa poin penting dalam penelitian ini, diantaranya: (1) Mahaiswa dalam mengikuti proses pembelajaran masih terkesan terpaksa, sehingga perhatiannya tidak terlalu fokus pada pembelajaran; (2) tidak terbangunnya interaksi antara peneliti dengan mahasiswa, antara siswa dengan mahasiswa; (3) Masih ada sebagian siswa yang belum menyadari pentingnya bekerjasama dalam kelompok

\section{Siklus II}

\section{Aktivitas belajar hasil observasi}

Tabel 4. Aktivitas Mahasiswa Dalam

\begin{tabular}{|c|c|c|c|c|c|c|c|}
\hline \multirow{2}{*}{ NO } & \multirow{2}{*}{$\begin{array}{c}\text { AKTIFITAS } \\
\text { SISWA }\end{array}$} & \multicolumn{3}{|c|}{ PERTEMUAN } & \multirow{2}{*}{\multicolumn{2}{|c|}{$\begin{array}{l}\text { RATA- } \\
\text { T RATA }\end{array}$}} & \multirow{2}{*}{$(\%)$} \\
\hline & & I & II & III & & & \\
\hline 1 & $\begin{array}{l}\text { Mendengarkan } \\
\text { penjelasan guru }\end{array}$ & 32 & 35 & 35 & $\begin{array}{l}\mathbf{E} \\
\mathbf{S}\end{array}$ & 34 & 97.14 \\
\hline 2 & $\begin{array}{l}\text { Menyusun } \\
\text { pertanyaan dan } \\
\text { mencari } \\
\text { jawaban }\end{array}$ & 16 & 17 & 20 & $\begin{array}{l}\text { S } \\
\mathbf{I} \\
\mathbf{K} \\
\mathbf{L}\end{array}$ & 17.67 & 50.48 \\
\hline 3 & $\begin{array}{l}\text { Aktif dalam } \\
\text { diskusi } \\
\text { kelompok }\end{array}$ & 24 & 25 & 25 & $\begin{array}{l}\mathbf{U} \\
\mathbf{S}\end{array}$ & 24.67 & 70.48 \\
\hline
\end{tabular}
Pembelajaran Siklus II

\begin{tabular}{|c|c|c|c|c|}
\hline No & Interval & Kategori & Frekuensi & $\begin{array}{c}\text { Persentase } \\
(\%)\end{array}$ \\
\hline 1 & $0-34$ & $\begin{array}{l}\text { Sangat } \\
\text { Rendah }\end{array}$ & 1 & 2.86 \\
\hline 2 & $35-54$ & Rendah & 2 & 5.71 \\
\hline 3 & $55-69$ & Sedang & 1 & 2.86 \\
\hline 4 & $70-84$ & Tinggi & 22 & 62.86 \\
\hline 5 & $85-100$ & $\begin{array}{l}\text { Sangat } \\
\text { Tinggi }\end{array}$ & 9 & 25,71 \\
\hline \multicolumn{3}{|c|}{ Jumlah } & 35 & 100 \\
\hline
\end{tabular}
Belajar Kimia Siklus II

Pada siklus II, kemampuan mahasiswa dalam menyusun peta konsep dan bekerja sama sudah semakin terlihat. Hal ini menunjukkan peningkatan pemahaman konsep materi yang dipelajari.

\section{PEMBAHASAN}

\section{Aktivitas Belajar}

Data perbandingan aktivitas siklus I dan siklus II, menunjukkan mahasiswa yang mengajukan pertanyaan pada siklus I sebanyak $22.85 \%$ mengalami peningkatan pada siklus II sebanyak $29.51 \%$. Mahasiswa yang mendengarakan penjelasan mengalami peningkatan dari $81.91 \%$ menjadi $97.14 \%$ pada siklus II. Begitupun mahasiswa yang menyusun pertanyaan dan mencari jawaban pada siklus I sebanyak $37.14 \%$ meningkat $50.48 \%$. mahasiswa yang aktif dalam diskusi
kelompok meningkat dari siklus I sebesar $60.94 \%$ menjadi $70.48 \%$ pada siklus II dan mahasiswa yang menyampaikan ide meningkat dari 38.08 menjadi $47.67 \%$ begitupun mahasiswa yang menjawab pertanyaan dari $20.85 \%$ menjadi $31.43 \%$ pada siklus II.

Hasil Belajar Mahasiswa

a. Perbandingan Nilai Statistik Siklus I dan Siklus II 


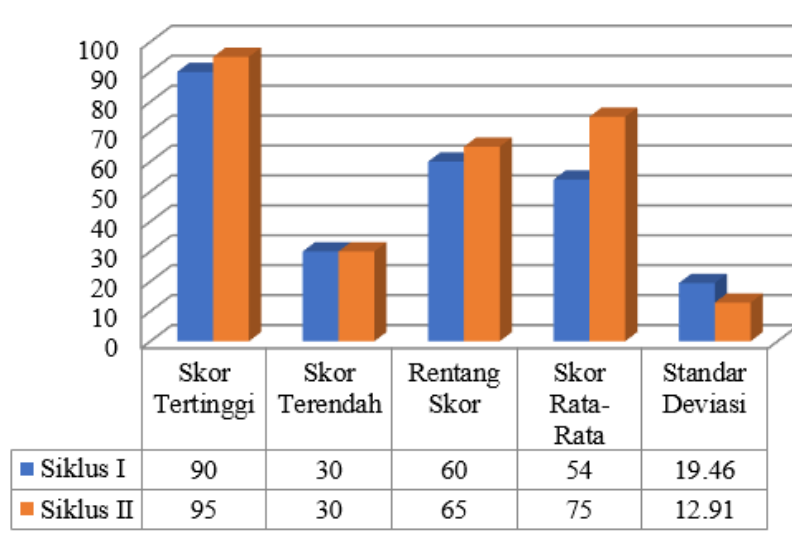

Gambar 1. Perbandingan Nilai Statistik Siklus I dan Siklus II

Pada Gambar 1 menunjukkan skor tertinggi dari siklus I (90\%) mengalami peningkatan pada siklus II (95\%), dan juga rentang skor mengalami peningkatan. Serta Skor rata-rata mengalami peningkatan pada siklus I (54) menjadi (75) pada siklus II.

\section{b. Perbandingan Kategori Hasil Belajar Siklus I dan Siklus II}

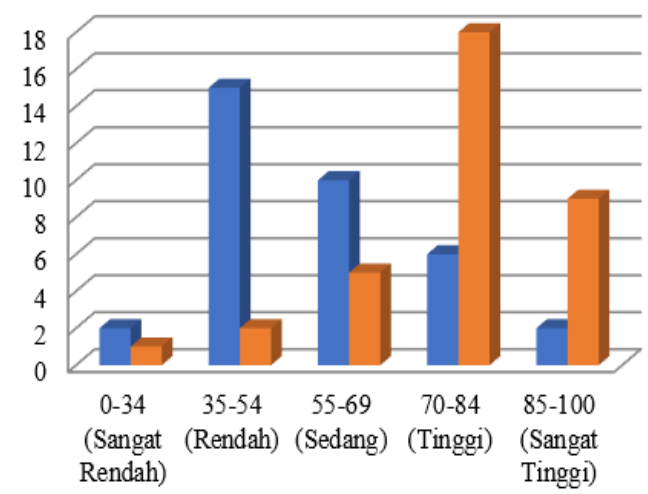

- Siklus I

- Siklus II

Gambar 2. Perbandingan Kategori Hasil Belajar Siklus I dan Siklus II

Berdasarkan hasil penelitian dari dua siklus, dapat dilihat bahwa siklus II ini menunjukkan kemajuan dari siklus I. Dalam hal peningkatan hasil belajar biologi dengan menggunakan pembelajaran berbasis concept mapping dipadu Teams Games Tournament, mahasiswa terbiasa untuk bisa bekerja sama dan tidak hanya menganggap mahasiswa yang lain sebagai saingannya, melainkan mereka dianggap sebagai rekan belajar yang bisa memotivasi dirinya dalam proses pembelajaran.

Keberhasilan siklus II ini terlihat pada kenaikan yang signifikan hasil belajar kimia dasar mahasiswa pada kategori tinggi dan sangat tinggi. Pengamatan ini memberikan gambaran peningkatan hasil belajar mahasiswa pada siklus II ditandai dengan penerapan Model Pembelajaran kimia berbasis Concept Mapping dipadu Teams Games Tournament membuat kegiatan pembelajaran menjadi lebih aktif. Hal ini ditunjukkan dengan peningkatan keterlibatan mahasiswa yang ikut aktif untuk berpartisipasi dalam pembelajaran.

Berdasarkan hasil penelitian dan analisa data mengenai perbandingan nilai statistik, perbandingan kategori hasil belajar dan perbandingan tingkat ketuntasan kedua siklus telah menunjukkan adanya peningkatan aktivitas dan hasil belajar mahasiswa dari siklus I ke siklus II.

\section{KESIMPULAN}

Berdasarkan hasil penelitian yang telah dipaparkan, dapat disimpulkan bahwa penerapan model Concept Mapping dipadu Teams Games Turnamen dapat meningkatkan hasil belajar kimia dasar mahasiswa STKIP PI Makassar yang ditandai dengan peningkatan kategori hasil belajar dari siklus I ke siklus II. Pada siklus I berada pada kategori sedang yaitu 10 orang mahasiswa atau $28,58 \%$ dan meningkat di siklus II pada kategori tinggi yaitu 22 orang siswa atau $62,86 \%$, terjadi peningkatan rata-rata hasil belajar mahasiswa yaitu pada siklus I 54,14 dan meningkat pada siklus II menjadi 75,43. Serta peningkatan ketuntasan belajar mahasiswa pada siklus I yaitu 11 orang atau 47.14 dan meningkat pada siklus II menjadi yaitu 31 orang $88,57 \%$.

\section{UCAPAN TERIMA KASIH}

Terimakasih penulis ucapkan kepada STKIP PI Makassar atas segala dukungan dan kesempatan yang telah diberikan kepada penulis untuk dapat melaksanakan penelitian ini.

\section{DAFTAR PUSTAKA}

Hamdayama, Jumanta. (2016). Metodologi Pengajaran. Jakarta: PT. Bumi Aksara. 
Mulyasa, E. (2014). Pengembangan dan Impelementasi Kurikulum 2013. Bandung: PT Remaja Rosdakarya.

Naniastuti, I., Nurvitasari, E., \& Marlissa, I. (2019). Perbandingan Model Pembelajaran Think Talk Write Dan Make a Match Terhadap Prestasi Belajar Kimia Siswa Kelas Xi Sma Ypk Merauke. Musamus Journal of Science Education, 1(2), 074-082. https://doi.org/10.35724/mjose.v1i2.1699

Pongkendek, J. J., Marpaung, D. N., \& Siregar, L. F. (2019). Analisis Motivasi Belajar Siswa Dengan Penerapan Model Pembelajaran Kooperatif Tipe Team Games Tournament. Musamus Journal of Science Education, 2(1), 31-38.

https://doi.org/10.35724/mjose.v2i1.2243

Darnella, R., Afriansyah, D., \& Syarifah. (2020). Penerapan Metode Concept Mapping ( Peta Konsep) dan Pengaruhnya Terhadap Kemampuan Berpikir Kritis Siswa pada Materi Sistem Gerak di MAN 1 Palembang. Jurnal Intelektualita: Keislaman, Sosial, dan Sains, 9 (1), 73-86

Ratieh, W. dan, \& Fachrurrozie. (2014). Teams Games Tournament (Tgt) Sebagai Metode Untuk Meningkatkan Keaktifan Dan
Kemampuan Belajar. Dinamika Pendidikan Unnes, 9(1), 48-56. https://doi.org/10.15294/dp.v9i1.3355

Sanjaya, Wina. (2012). Strategi Pembelajaran Berorientasi Standar Proses Pendidikan. Jakarta: Kencana Prenada Media

Sugiyono. (2011). Metodologi penelitian kuantitatif kualitatif dan $R \& D$. Alfabeta.

Taniredja, T. (2011). Model-Model Pembelajaran Inovatif. Bandung: Alfabeta.

Tarmidzi, T. (2019). Belajar Bermakna (Meaningful Learning) Ausubel Menggunakan Model Pembelajaran Dan Evaluasi Peta Konsep (Concept Mapping) Untuk Meningkatkan Kemampuan Pemahaman Konsep Mahasiswa Calon Guru Sekolah Dasar Pada Mata Kuliah Konsep Dasar Ipa. Caruban: Jurnal Ilmiah Ilmu Pendidikan Dasar, 1(2), 131. https://doi.org/10.33603/cjiipd.v1i2.2504

Vitantri, C. A. (2017). Integrasi concise learning method dengan mind mapping dalam pembelajaran matematika di perguruan tinggi. Beta: Jurnal Tadris Matematika, 10(2), 203221. https://doi.org/10.20414/betajtm.v10i2.110 